\title{
Suidwesstories uit toeka se tyd
}

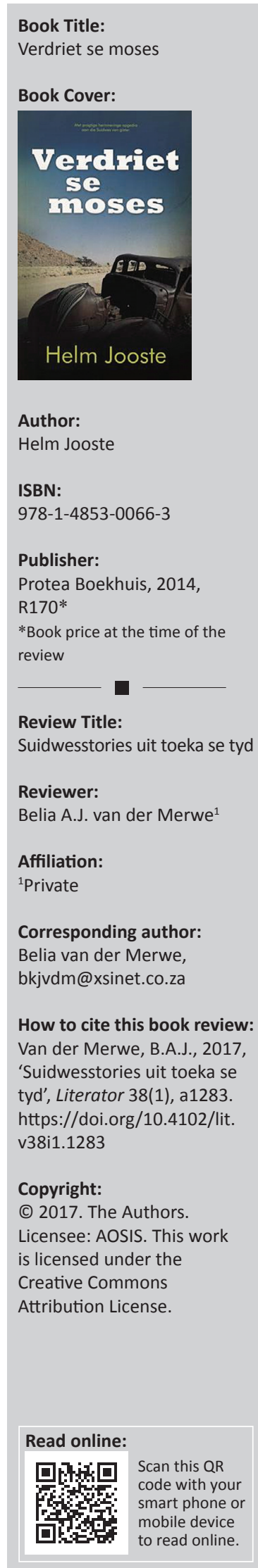

Verdriet se moses (2014) is 'n herdruk van Helm Jooste se bundel biografiese sketse en vertellings wat in 1996 verskyn het. Dit is voorafgegaan deur Daar doer in Duitswes (1989) en Dinge daar doer (1992). Soos daar voor in Verdriet se moses aangedui word, kan hierdie bundels inderdaad omskryf word as Nuwe stories uit die ou Suidwes.

Die verhale in Verdriet se moses handel oor mense en gebeure uit die skrywer se 50 jaar lange verblyf in die destydse Suidwes-Afrika. 'n Paar speel af teen die agtergrond van sy kinder- en skooljare in Transvaal. Die talle biografiese feite wat so tussen die vermaaklike vertellings deur met die leser gedeel word, gee 'n kykie in die veelbewoë lewe van die skrywer. Hy bring sy kinderjare deur op 'n plaas in die Hoëveld in die omgewing van Bethal en matrikuleer aan Hoërskool Hoogenhout op dié dorp. Na sy onderwysopleiding aanvaar hy in 1931 'n pos in Suidwes, waarheen sy ouers ook 'n paar jaar vroeër verhuis het. Aanvanklik is hy 'n onderwyser by verskeie plaasskole, maar later ook boer en sakeman. Vroeg in die 1980's gaan vestig hy hom in die Strand. In 'n paar verhale maak die leser ook kennis met die skrywer se kinders en kleinkinders.

Die bundel open met "n Werfstorie' (bl. 7) waarin 'n selfversekerde matriekseun wat een nag by hulle op die plaas in die vrykamer oorslaap - waar die skrywer se ouma kort vantevore gesterf het - behoorlik die skrik op die lyf gejaag word deur 'n naguil en Ou Tom, die werfkat. Fred Mouton se meesterlike illustrasie vang die presiese moment vas toe die verskrikte gas met ' $n$ boog tussen die skrywer se ouers in hulle bed duik.

'n Ander verhaal uit die skrywer se jeugjare het 'n veel soberder strekking. In 'Wat moet wees, moet wees' (bl. 34) vertel hy van sy en Kiewiet se byna idilliese kinderjare op aangrensende plase. Hy onthou haar as "n Sonskynmens. So eie aan die plaas soos die lelie aan die vlei' (bl. 35). Na hul opleiding by die onderwyskollege op Heidelberg loop hul paaie egter ver uitmekaar en toe hy haar in 1968 weer opspoor, herken hy sy eertydse speelmaat en vriendin glad nie in die lewelose grys ou vroutjie wat voor hom staan nie. 'Op haar gesig is die spore van jare se leed' (bl. 40). Die verhaaltitel is 'n vertaling van 'whatever will be, will be' uit die nostalgiese liedjie 'Que será, será'. Terwyl Kiewiet die verteller alleen in die klein onversorgde woonkamertjie los om brandewyn by haar buurvrou te gaan leen, tel hy van die vloer af 'n stuk papier op waarop sy die woorde van dié liedjie geskryf het.

Dit is 'n lang ry interessante mense - oudleerlinge en hul ouers, vee- en velkopers, 'n Duitse baron, medeboere, vistermanne en baie ander - wat deur hierdie verhale paradeer. Die skrywer skroom egter nie om ook met homself die spot te dryf nie, byvoorbeeld in "n Hand vol vere' (bl. 95) waar hy vir sy kleinseun drie kapokhoenders koop en later op geen manier van die luidrugtige haantjie en twee hennetjies ontslae kan raak nie, niemand wil hulle eens present hê nie.

In 'Sy verdiende loon' (bl. 79) maak die skrywer se ma 'n opmerking wat ook op hom van toepassing is: 'Jou pa is 'n Jooste, my kind. As Joostes nie probleme het nie, koop hulle dit' (bl. 79). Die skrywer vertel van etlike kompulsiewe aankope wat hom deur die jare groot probleme besorg het, soos byvoorbeeld die indrukwekkende maar erg befoeterde boerbokram wat hy op die ingewing van die oomblik aanskaf en agter op sy bakkie moet laai vir die rit plaas toe. 'My gelukkige dag' (bl. 118) handel oor sy noue ontkoming toe hy vinnig en sonder om te dink gebie het op 'n stukkie grond van tien hektaar naby Windhoek. Sy bod, wat hy glad nie kon bekostig nie, was wel die hoogste, maar die eienaar het meer verlang. 'Berge kommer en selfverwyt val van my skouers. Halleluja! Ek is sowaar heelhuids uit die gemors!' (bl. 120.)

In Verdriet se moses word 'n paar pittige staaltjies opgeneem wat die skrywer by ander mense gehoor het, maar merendeels verwoord hy sy eie ervarings en belewenisse. In een van die verhale 'Lorraine en haar apie' (bl. 88) stel hy twee eerstepersoonvertellers aan die woord hyself en sy vrou. Hy was immers nie by toe sy met hulle nuwe motor op die buurplaas gaan 
kuier het nie. Hier wip buurvrou Lorraine se onnutsige mak apie deur die oop motorruit en kom af op die twee dosyn eiers wat sy vrou as geskenk saamgebring het, maar nie dadelik kon aflaai nie. Hy is vanselfsprekend erg ontstoke toe sy vrou hom van die petalje inlig:

Ek wil die motor in daardie toestand nie sien nie! Glad nie. Laat Lorraine en haar bleddie aap jou help! Kry droogskoonmakers of Pupkewitz se winkel, die army, of enigiemand anders. Sorg net asseblief dat dit skoon kom. As daar een eierdoppie of eierkolletjie of eierreukie of eier-wat-ook-al oorbly, verkoop ek die ding onmiddellik! (bl. 94).
Die kaart van Suidwes voor in Verdriet se moses waarop die vernaamste dorpe en paaie aangedui word, is 'n welkome toevoeging tot die bundel. Dit gee die leser 'n idee van die ligging van die dorpe en plekke - van Nakop in die suide tot Etoshapan in die noorde - wat in die verhale ter sprake kom.

Fred Mouton slaag met sy humoristiese en lewendige illustrasies daarin om die hoogtepunt van elke vertelling vas te vang. Jooste se beskrywings en Mouton se tekeninge is ' $n$ wenkombinasie wat sorg vir groot leesplesier en inderdaad enige verdriet se moses is! 